\title{
SCIENTIFIC AND THEORETICAL FOUNDATIONS OF INFORMATION SUPPORT FOR ADMINISTRATIVE LEGAL PROCEEDINGS IN UKRAINE
}

\section{Shkuta O. O.}

\section{INTRODUCTION}

The evolution of domestic legislation regulating information relations in the field of legal proceedings takes place in stages and depends on many factors, the main of which are the development of information technology, legal reforms, and the implementation of international law.

The legal basis of information provision in general was considered in the works of such legal scholars as: L.V. Balabanov, Ye.Yu. Barash, Ye.D. Bondarenko, O. Iierusalymov, R.A. Kaliuzhnyi, O.V. Kostenko, V.V. Lusher, P.V. Makushev, S.M. Petrenko, A.V. Chernoivanenko, V.V. Halunko, O.K. Yudin, and others. The issue of information provision of legal proceedings was investigated by O.V. Bryntsev, O.I. Korchynskyi, Ye.I. Ovchynnykov, V.B. Pchelin, I.O. Turkina, and others. A small number of scholars who investigated namely the issue of information provision of legal proceedings testify to the complexity of this problem and the need to intensify scientific research in this area. Significant volumes of relations in the field of information provision of legal proceedings led only to a fragmentary study of their legal regulation. Recent changes in the procedural law have significantly increased the number of legal rules governing the information provision of administrative legal proceedings and introduced new unexplored and completely unformed legal institutions. The abovementioned determines the relevance of the submitted scientific article.

According to O.V. Bryntsev, e-justice is one of the elements of edemocracy, which is being implemented in order to ensure accessibility, accountability, the effectiveness of feedback, inclusiveness, transparency in the activities of state authorities. Judiciary is a key component of democracy, so it is fairly considered that e-justice is the most important front of edemocracy $^{1}$. For the effective functioning of the state and all state mechanisms, information provision of administrative legal proceedings of Ukraine is of key importance. As V.B. Pchelin notes, the proper functioning of administrative legal proceedings of Ukraine, within which the

${ }^{1}$ Бринцев О.В. “Електронний суд” в Україні. Досвід та перспективи: монографія. Х.: Право, 2016. 72 с. 
consideration and resolution of public-law disputes related to the protection and restoration of violated, unrecognized, disputed rights, freedoms, and interests of individuals and legal entities take place, may be only in the case of its effective information support ${ }^{2}$. The content and scope of information relations arising in the field of administrative legal proceedings with each stage of development of domestic information and procedural legislation are increasingly specified. At the same time, the growth of the circle of such relations, the increase of the types of information used within the administrative legal proceedings, and the growing importance of information support for administrative legal proceedings are observed. The current legal community of Ukraine is looking for ways to optimize the work of the entire judicial system in general and administrative legal proceedings in particular.

The volume of cases handled by administrative courts remains significant every year. Thus, in 2016, 215319 administrative cases were received for consideration by local administrative courts, and 76184 cases - by administrative courts of appeals ${ }^{3}$. In 2017, 121692 cases were submitted for consideration to the local administrative courts and 73496 cases - to the administrative courts of appeal ${ }^{4}$. Accordingly, the amount of information used to resolve such a circle of cases invariably grows; the need for optimization of information databases, their integration, and improving the efficiency of the search for the necessary information increases.

\section{Information support of administrative proceedings in Ukraine}

One of the most important characteristics of the state, which significantly affects all processes of the socio-economic development of society, is the level of information provision of the system of state power, as I.M. Oliichenko emphasizes. Many years of experience in improving public administration confirms that information provision should be considered as one of the strategic directions for improving the efficiency of its activities at all levels: state, branch, regional, international ${ }^{5}$. P.V. Makushev emphasizes that information provision of each civil service is an important element of its

${ }^{2}$ Пчелін В.Б. Перегляд адміністративних актів органів внутрішніх справ: дис. ... канд. юрид. наук: 12.00.07 “Адміністративне право і процес; фінансове право; інформаційне право”. Х., 2011. с. 121.

3 Нечитайло О.М. Адмінсуди організовують роботу так, щоб суспільство могло примусити органи державної влади та посадовців поважати права громадян. URL: http://www.vasu.gov.ua/archive/123741/.

${ }^{4}$ Ефективність роботи судів за 2017 рік / Державна судова адміністрація України. URL: https://ln.kr.court.gov.ua/dsa/pokazniki-diyalnosti/efekt_roboti_sudiv1/efekt_2017.

5 Олійченко I.M. Інформаційне забезпечення управління обласною державною адміністрацією. URL: http://www.dridu.dp.ua/zbirnik/2011-01(5)/11 oimoda.pdf. 
functioning ${ }^{6}$. As V.V. Lusher notes, the science of administrative law widely uses this term: "administrative legal support", "the mechanism of administrative legal support", "ensuring rights and freedoms of citizens", "ensuring public safety", etc. ${ }^{7}$

In the dictionaries, the term "provision" is interpreted in similar terms, but they have certain differences. Thus, in the new explanatory dictionary of the Ukrainian language, it is considered in two meanings: 1) the provision or creation of material resources; 2) guaranteeing something ${ }^{8}$. In the great explanatory dictionary, the term "provision" is explained through the verb "to provide", which is used in several meanings: "to create reliable conditions for the implementation of something"; "to guarantee something"; "to defend, to protect someone, anything from danger". The above interpretation of the concept of "provision" allows considering it as an activity, a system of measures aimed at improving something specific. So, one can agree with the conclusion of V.B. Pchelin that the category of "provision" is denoted by a long process aimed at guaranteeing the functioning of the relevant institution, maintaining it in good condition in order to fulfil its tasks ${ }^{10}$.

The term "provision" can be used in various areas of legal regulation and have some peculiarities depending on it. However, for the purpose of studying the issues of information provision of administrative legal proceedings, the results of the search of scientists are important in terms of approaches to the content of the concept of information provision. So, R.A. Kaliuzhnyi, investigating information provision of a management system, proposes to understand it as a combination of all the information used, specific means and methods of its processing, as well as the activities of specialists on the efficient use of data, information, knowledge in the management of a particular system ${ }^{11}$. Studying the information provision of management, S.M. Petrenko believes that it is a set of implemented decisions on the

\footnotetext{
${ }^{6}$ Макушев П.В. Система інформаційного забезпечення державної виконавчої служби України та персональні дані як їх складові. Право і суспільство. 2013. № 4. С. 70-77.

7 Лушер В.В. Поняття інформаційного забезпечення органів прокуратури України. Форум права. 2014. № 1. С. 338-341. URL: http://nbuv.gov.ua/UJRN/ FP_index.htm_2014_1_59

8 Новий тлумачний словник української мови: в 4 т. / укл.: В.В. Яременко, О.М. Сліпушко. К.: Аконіт, 1999. С. 684.

${ }^{9}$ Словник української мови: в 11 т. / за ред. І.К. Білодіда. К.: Наукова думка, 1972. Т. 3. 630 с.; Словник української мови: в 11 т. / за ред. І.К. Білодіда. К.: Наукова думка, 1977. T. 8. C. 19.

10 Пчелін В.Б. Правові засади інформаційного забезпечення адміністра- тивного судочинства України. Підприємництво, господарство і право. 2016. № 8. С. 120.

${ }^{11}$ Калюжний Р.А., Гавловський В.В., Гуцалюк М.А. та ін. Інформаційному суспільству України інформаційне законодавство (щодо питань реформувань у сфері суспільних інформаційних відносин). Правове, нормативне та метрологічне забезпечення системи захисту інформації в Україні. 2001. № 2. С. 11.
} 
volumes of information, its qualitative and quantitative composition, location, and forms of organization, the purpose is timely provision of necessary and sufficient information for the adoption of managerial decisions that ensure the effective operation of both the enterprise as a whole and its structural subdivisions $^{12}$.

O.K. Yudin and V.M. Bohush, studying the provision of information security, define it as a set of measures designed to achieve the state of protection of the needs of individuals, society, and the state in information ${ }^{13}$.

Directly informational support as an independent concept, L.V. Balabanova proposes to understand as a set of actions to provide the necessary management information in the specified place on the basis of certain procedures with a given periodicity ${ }^{14}$; A.V. Chernoivanenko - as a system for managing the totality of representations, concepts, data, and as activities related to means of collecting, registering, transmitting, storing, processing, and presenting information ${ }^{15}$.

A. Tytorenko - as the most important element of information systems and information technology, designed to display information that characterizes the state of the controlled object and which is the basis for the adoption of management decisions, and includes a set of unified system of indicators, flows of information - options for document management; systems of classification and coding of economic information, unified documentation system, and various information arrays (files) stored in a computer and technical carriers and having different degrees of organization $^{16}$; Ye.D. Bondarenko - as a process to meet the needs for information based on the use of special means and methods for its acquisition, processing, accumulation, and output in easy-to-use form, and the structure of this provision includes an information fund and special techniques and methods of information provision, i.e., this phenomenon simultaneously represents, firstly, a certain organizational activity of obtaining, processing, accumulation, and output of information, secondly, methods and techniques of

12 Петренко С.М. Інформаційне забезпечення внутрішнього контролю господарських систем: монографія. Донецьк: ДонНУЕТ, 2007. С. 20.

${ }^{13}$ Юдін О.К., Богуш В.М. Інформаційна безпека держави: навч. посібник. Х.: Консум, 2005. C. 52.

14 Балабанова Л.В., Алачева Т.И. Информационное обеспечение обосно- вания управленческих решений в условиях маркетинговой ориентации пред- приятия: монография. Донецк: ДонГУЭТ им. М. Туган-Барановского, 2003. С. 9.

15 Черноіваненко А.В., Галунько В.В. Інформаційне забезпечення підготовки, прийняття та реалізації управлінських рішень: теоретичний підхід до визначення поняття. URL: http://www.kbuapa.kharkov.ua/e-book/conf/2009-1/doc/35.pdf.

16 Информационные технологии управления: учеб. пособие для вузов / под ред. Г.А. Титоренко. 2-е изд., доп. М.: ЮНИТИ-ДАНА, 2003. с. 15 
its implementation, and thirdly, certain material objects - information fund; I.O. Iierusalymov defines it as an act, as well as storage, performance of something that serves as a guarantee of one or another process ${ }^{17}$.

Investigating the information support of the state criminal-executive service, Ye.Yu. Barash defines its main features, namely: in its essence, it acts as a process of processing, obtaining, storing, and using management information about various aspects of the functioning of the service; by a periodicity it represents an uninterrupted process of processing and using information; by the nature of existence it is a part of the management of the service; by the form of implementation, it is carried out using means and methods inherent in this type; by the consequences of the implementation of information provision, it is associated with the formation of certain information funds, documents, regulatory framework; for the purpose of functioning, it is aimed at ensuring the proper functioning of the system, for example, an automated control system; for the main purpose as an instrument of effective management, it finds its implementation in the analysis, planning, and preparation of effective managerial decisions ${ }^{18}$. Studying the information provision of the state executive service, P.V. Makushev defines it as a part of managerial activity in the analysis, planning, and preparation of management decisions, which is an uninterrupted process of processing and using information on the state of the functioning of the state executive service system, which is carried out with the help of information tools and methods, leads to the formation of information funds, and aims to ensure the proper functioning of the system of the state executive service of Ukraine ${ }^{19}$. O.V. Kostenko determined the features inherent in information provision in more detail, taking into account its content, methods of implementation, goal, purpose $^{20}$.

Taking into account features of administrative legal proceedings, the most modern definition of its information provision is formulated by V.B. Pchelin. Thus, this scholar proposes to understand the information support of administrative legal proceedings of Ukraine as the set of measures based on

17 Ієрусалимов I.O. Поняття “забезпечення” у юридичній науці. Науковий вісник Київського національного університету внутрішніх справ. 2007. № 1. С. 12.

18 Бараш Є.Ю. Інформаційне забезпечення управління Державною кримінальноювиконавчою службою. Форум права. 2011. № 3. С. 35. URL: http://www.nbuv.gov.ua/ejournals/FP/2011-3/11beikvc.pdf.

${ }^{19}$ Макушев П.В. Персональні дані як елемент системи інформаційного забезпечення державної виконавчої служби України. Форум права. 2013. № 2. С. 335 . URL: http://nbuv.gov.ua/UJRN/FP_index.htm_2013_2_51.

${ }^{20}$ Костенко О.В. Інформаційне забезпечення регіональних прокуратур та інформація 3 обмеженим доступом. Форум права. 2016. № 1. C. 116. URL: http://nbuv.gov.ua/UJRN/ FP_index.htm_2016_1_21. 
the requirements of the current national legislation on the operation (collection, fixation, analysis, storage, dissemination, etc.) of information that is implemented in the framework of the performance of its functions by authorized subjects and due to the functioning of automated systems and aimed at ensuring the proper functioning of administrative courts for the consideration and resolution of public-law disputes ${ }^{21}$. In our view, the term of operating information is not traditional in the field of law and its use in this area needs a deeper justification. Therefore, in our opinion, in the proposed by V.B. Pchelin definition, the term "operation" is proposed to be replaced by the term "circulation". In the current legislation of Ukraine, the term "circulation", which can be applied to information, is defined in the Law of Ukraine "On Electronic Document Circulation)). So in Article 9 of this law, electronic document flow is defined as a set of processes for creating, processing, sending, transmitting, receiving, storing, using, and destroying electronic documents that are performed using integrity checking and, if necessary, confirming the fact of receipt of such documents. Thus, in the opinion of the legislator, the information circulation includes its processing. At the same time, an electronic document, under Art. 5 of this law, is a document, the information in which is recorded in the form of electronic data, including the mandatory details of the document ${ }^{22}$. Although the concept of an electronic document is somewhat narrower than the concept of information, in general, we believe that the concept of electronic document circulation characterizes the content of the concept of information circulation.

Information provision of administrative legal proceedings is carried out in the course of activities of authorized entities, as well as through the operation of the relevant automated systems.

V. B. Pchelin stresses that the judges as the main subjects of cognition in the administrative process, the State Judicial Administration of Ukraine, and the courts are the main subjects that carry out the information provision of administrative legal proceedings ${ }^{23}$. At the same time, according to Art. 147 "System of Ensuring the Functioning of the Judiciary" of the Law of Ukraine "On the Judiciary and Status of Judges" in Ukraine there is a unified system of ensuring the functioning of the judiciary - courts, bodies of the judiciary,

${ }^{21}$ Пчелін В.Б. Сутність інформаційного забезпечення адміністративного судочинства в Україні. Науковий вісник Ужгородського національного університету. Серія "Право". 2016. № 39. С. 22-25.

22 Про електронні документи та електронний документообіг: Закон України від 22 травня 2003 р. № 851-IV / Верховна Рада України. Відомості Верховної Ради України. 2003. № 36. Ст. 275.

${ }^{23}$ Пчелін В.Б. Сутність інформаційного забезпечення адміністративного судочинства в Україні. Науковий вісник Ужгородського національного університету. Серія "Право”. 2016. № 39. С. 24. 
other state bodies and institutions of the system of justice. This system includes: the Supreme Council of Justice, the High Qualifications Commission of Judges of Ukraine, the State Judicial Administration of Ukraine, and the National School of Judges of Ukraine, other bodies of state authority and local self-government bodies are involved in the organizational support of the activities of courts in the cases and in accordance with the procedure established by this and other laws ${ }^{24}$. According to Articles 152 and 155 of the Law of Ukraine "On the Judiciary and Status of Judges", the State Judicial Administration of Ukraine and the court apparatus have the basic authority regarding the information provision of administrative justice in the system of bodies for ensuring the functioning of the judiciary.

Information support for administrative legal proceedings is provided through the functioning of the relevant information systems. At present, such systems are the Unified State Register of Court Decisions, the Register of Electronic Addresses of State Authorities, their Officials and Officers, the Automated System of Court Documents, the Single Judicial Information and Telecommunication System ${ }^{25}$. According to Article 18 of the CALP, the Single Judicial Information and Telecommunication System operates in courts, which was created for the fulfilment of such tasks as: registration of documents coming to court; determination of a judge for the consideration of a case; exchange of documents electronically between courts, as well as between the court and the participants in the trial; fixing the trial and participation of participants in the trial in a court session in a video conferencing mode. However, the adoption of the provision on this system still requires time and certain measures. Thus, the State Judicial Administration of Ukraine has elaborated a Plan of Measures for the Implementation of the Law of Ukraine on 03.10.2017 $\mathrm{N}^{\circ}$ 2147-VIII "On Amendments to the Commercial Procedural Code of Ukraine, the Civil Procedural Code of Ukraine, the Code of Administrative Legal Proceedings of Ukraine, and other legislative acts" ${ }^{\prime 2}$. Consequently, as V.B. Pchelin emphasizes, the corresponding automated information systems serve as

${ }^{24}$ Про судоустрій та статус суддів: Закон України від 2 червня 2016 р. № 1402-VIII / Верховна Рада України. Відомості Верховної Ради України. 2016. № 31. С. 7. Ст. 545.

${ }^{25}$ Щодо Положення про автоматизовану систему документообігу суду: Рішення Ради суддів України від 26 листопада 2010 р. № 30 / Рада суддів України. Вісник Верховного Суду України. 2010. № 51. С. 5.

26. Про затвердження Плану заходів щодо реалізації Державною судовою адміністрацією України Закону України "Про внесення змін до Господарського процесуального кодексу України, Цивільного процесуального кодексу України, Кодексу адміністративного судочинства України та інших законодавчих актів” від 3 жовтня 2017 р. № 2147-VIII: Наказ Державної судової адміністрації України від 22 грудня 2017 р. № 1126 / Державна судова адміністрація України. URL: https://dsa.court.gov.ua/userfiles/file/DSA/DSA_2017_all_docs/17ordersmarch/ N_1126.pdf. 
important constituent elements of the information provision of administrative legal proceedings, because precisely due to their functioning: the subjective factor is eliminated; tasks on information provision are carried out continuously and promptly; everyone, except for cases provided by law, is provided with the necessary information on administrative legal proceedings and other related data in this area ${ }^{27}$. It is through the information support for administrative legal proceedings that the principles of its publicity, openness, and transparency are implemented.

\section{Legal fundamentals of information provision of administrative legal proceedings in Ukraine and the stages of their formation}

Under the legal principles of information provision of administrative legal proceedings, V.B. Pchelin proposes to understand the totality of legal acts of various legal force, which, taking into account their hierarchical links, carry out statutory regulation of the activities of authorized entities and the functioning of automated information systems with the operation of information in order to ensure proper activities of administrative courts for the consideration and resolution of public-law disputes.

The current state of legal regulation of information provision of administrative legal proceedings preceded the long period of development of domestic administrative-procedural and information legislation. The general principles of information provision of administrative legal proceedings are determined by the following laws of Ukraine: "On Personal Data Protection" on June 1, 2010; "On Court Fees" on July 8, 2011; "On Appeal of Citizens" on October 2, 1996;

"On State Secrets" on January 21, 1994; "On Electronic Documents and Electronic Document Circulation" as of May 22, 2003; "On Electronic Digital Signature" on May 22, 2003; "On Information " dated October 2, 1992; "On Access to Public Information" on January 13, 2011; "On Information Protection in Information and Telecommunication Systems" dated July 5, 1994; etc. Special laws and regulations detail the order of information provision of administrative legal proceedings.

The stages of formation of the legal regulation of information provision of administrative legal proceedings, determined by us, are based on large-scale structural changes that have led to global processes in the field of information provision of administrative legal proceedings.

We associate the first stage of the formation of legislation regulating the information provision of administrative legal proceedings with the adoption of

27 Пчелін В.Б. Правові засади інформаційного забезпечення адміністра- тивного судочинства України. Підприємництво, господарство і право. 2016. № 8. С. 121. 
the Code of Administrative Legal Proceedings of Ukraine (hereinafter referred to as CALP) on July 6, 2005. Thus, the first edition of the CALP identified such important components of the information provision of administrative legal proceedings as the principles of transparency and openness of the administrative process (Article 12), the principles of recording the court session by technical means (Article 41), reproduction and printing of the technical record of the court session (Article 44); types of procedural information and its carriers.

The second stage of the formation of legal norms regulating information provision of administrative legal proceedings is connected with the introduction of an automated system of document circulation in administrative courts. The Law of Ukraine "On Amendments to Certain Legislative Acts of Ukraine Regarding the Introduction of Automated System of Document Circulation in Administrative Courts" on June 5, 2009, No. 1475-VI supplemented the CALP by Art. 15-1 "Automated System of Court Documents". By the Order of the State Judicial Administration of Ukraine as of 03.12.2009 $\mathrm{N}^{\circ}$ 129, the provision "On Automated System of Document Circulation in Administrative Courts" ${ }^{28}$ was approved, which expired pursuant to the Decision of the Council of Judges of Ukraine as of 26.11.2010 No. 30, which introduced the Regulation on the Automated System of Document Circulation of the Court ${ }^{29}$.

The second stage in the formation of information provision of administrative legal proceedings is also characterized by a fragmentary development of certain rules regulating the information provision of certain categories of administrative cases. One of such legal acts, which caused changes in this area, is the Law of Ukraine "On Amendments to Certain Legislative Acts of Ukraine on Elections of the President of Ukraine" as of August 21, 2009, $\mathrm{N}^{\circ}$ 1616-VI, which identified the features of the use of procedural information under the proceedings in cases related to the election of the President of Ukraine ${ }^{30}$. The Law of Ukraine "On Alienation of Land Plots and Other Immovable Property Located Thereon, Which are in Private Property, for Public Needs or Social Necessity" on November 17, 2009,

28 Про автоматизовану систему документообігу в адміністративних судах: Наказ Державної судової адміністрації України від 3 грудня 2009 р. № 129 / Державна судова адміністрація України. Офіційний вісник України. 2010. № 101. С. 393. Ст. 3566.

${ }^{29}$ Щодо Положення про автоматизовану систему документообігу суду: Рішення Ради суддів України від 26 листопада 2010 р. № 30 / Рада суддів України. Вісник Верховного Суду України. 2010. № 51. С. 5.

${ }^{30}$ Про внесення змін до деяких законодавчих актів України щодо виборів Президента України: Закон України від 21 серпня 2009 р. № 1616-VI / Верховна Рада України. Відомості Верховної Ради України. 2009. № 50. С. 1816. Ст. 754. 
N 1559-VI, supplemented the CALP by Article 183-1 "Peculiarities of the Proceedings in Administrative Cases Concerning the Compulsory Alienation of a Land Plot, Other Objects", this article defines a circle of procedural information characteristic for this category ${ }^{31}$. Also, at this stage, there was an extension of the circle of legal norms regulating the information provision of certain stages and types of proceedings in administrative legal proceedings (Article 174, Article 183-2 of the CALP), the circle of information used in administrative legal proceedings was expanded, etc.

At this stage, the formation of the legal regulation of the information provision of administrative legal proceedings also introduces changes to Art. 12 "Publicity and Openness of Administrative Process" regarding the recording of the trial by technical means ${ }^{32}$.

The third stage of the formation of the legislation regulating information provision of administrative legal proceedings began on November 22, 2017, with the signing of the Law of Ukraine "On Amendments to the Commercial Procedural Code of Ukraine, the Civil Procedural Code of Ukraine, the Code of Administrative Legal Proceedings of Ukraine, and other legislative acts". This stage is characterized by the introduction of the electronic justice system at all stages of the process and the transition to the Single Judicial Information and Telecommunication System, the creation of the possibility of remote participation in the trial, the presentation of various documents, familiarization with the case. The specified system provides for the exchange of documents in electronic form between courts, between the court and participants in the trial, as well as recording the trial and participation of participants in the court proceedings in a court session in a video conferencing mode.

In accordance with the said law, the system of organization of legal proceedings in Ukraine undergoes certain changes, namely: obligatory registration of procedural documents in the system on the day they are received; committing any actions in electronic form using an electronic digital signature; automatic determination by the system of a judge or panel of judges for consideration of a particular case in accordance with the procedure established by the Codes; storage of case materials in electronic form; preservation of the right of the parties to the case to apply to the court in paper form and receive the relevant documents after the introduction of the system;

31 Про відчуження земельних ділянок, інших об'єктів нерухомого майна, що на них розміщені, які перебувають у приватній власності, для суспільних потреб чи з мотивів суспільної необхідності: Закон України від 17 листопада 2009 р. № 1559-VI / Верховна Рада України. Відомості Верховної Ради України. 2010. № 1. С. 3. Ст. 2.

32 Рішення Конституційного Суду України від 8 грудня 2011 р. № 16-рп/2011 (справа про фіксування судового процесу технічними засобами) / Конституційний Суд України. Вісник Конституційного Суду України. 2012. № 1. С. 31. 
obligation to broadcast a court session in a video conferencing mode via the Internet; functioning of the Unified State Register of Executive Documents ${ }^{33}$. The information provided indicates the phased development of the legal norms that are in the CALP and regulate the information relations in the administrative legal proceedings.

\section{CONCLUSIONS}

The conditional stages of the formation of the legal regulation of the information provision of administrative legal proceedings determined by us were based on events of key importance for the formation of the information support system of administrative legal proceedings and were accompanied by secondary fragmentary changes that concerned only information provision of certain types of administrative cases.

When investigating the information support of administrative proceedings, it is necessary to distinguish it from the information support of the administrative court. In our view, the information support of the administrative court is a part of the administrative activity for the analysis, planning, and preparation of management decisions, which is an uninterrupted process of processing and using information on the state of functioning of the court apparatus and work of judges, which is carried out with the help of information tools and methods, leads to the formation of information funds, and is aimed at ensuring the proper functioning of the administrative court. At the same time, as information provision of administrative legal proceedings of Ukraine, this is, based on the requirements of the current national legislation, a set of measures related to the circulation of procedural information, which are implemented in the framework of their functions by authorized agents and through the functioning of automated systems and aimed at ensuring the proper functioning of administrative courts on consideration and resolution of public-law disputes.

At the current stage of development of domestic legislation, the legal regulation of information provision of administrative legal proceedings is carried out in accordance with the following laws and regulations: Laws of Ukraine "On the Judiciary and Status of Judges", "On Amendments to Certain Legislative Acts of Ukraine on the Introduction of Automated System of Documentation in Administrative Courts"; "On Access to Court Decisions", "On Amendments to the Commercial Procedural Code of Ukraine, the Civil Procedural Code of Ukraine, the Code of Administrative Justice of Ukraine, and other legislative acts", the Code of Administrative Legal Proceedings of

33 Роїк О.В. Електронне судочинство. Чи має Україна шанси? URL: http:// yur-gazeta.com/dumka-eksperta/elektronne-sudochinstvo-chi-mae-ukrayina-shansi.html. 
Ukraine, as well as the Regulation "On Automated System of Documentation of the Court", the Procedure for the Management of the Single State Register of Court Decisions, the Regulation on the Single Database of Electronic Addresses, Fax Numbers (Telefaxes) of the Authorities. Some aspects of the information provision of administrative legal proceedings of Ukraine are regulated at the level of subordinate legislation adopted by the State Judicial Administration of Ukraine, which approve the Typical Job Instructions for Employees of the Administration of the Local General Court; Instruction on the Procedure for Working with Technical Means of Recording Court Proceedings (Court Sessions); Instruction on Case Management in Administrative Courts, etc.

The nearest changes in the system of information provision of the administrative process in accordance with the Action Plan on the implementation of the Law of Ukraine as of 03.10.2017 $\mathrm{N}^{\circ}$ 2147-VIII "On Amendments to the Commercial Procedural Code of Ukraine, the Civil Procedural Code of Ukraine, the Code of Administrative Legal Proceedings of Ukraine, and other legislative acts" is the introduction of the Unified State Register of Executive Documents and the Single Judicial Information and Telecommunication System.

\section{SUMMARY}

The article is devoted to the analysis of scientific concepts and the legal framework of the concept of information support for administrative legal proceedings. Features and peculiarities of information provision for administrative legal proceedings are studied; its differences from information support for the administrative court are stressed. The author's definitions of the concept of information support for the administrative procedure and information support for the administrative court are proposed. Three stages of formation of national legislation regulating information provision of administrative legal proceedings are singled out. The system of laws and regulations, which provisions consolidate legal fundamentals of information support for administrative legal proceedings, is clarified. Prospective directions for the development of scientific inquiry in the field of information support for administrative legal proceedings and its legal regulation are revealed.

\section{REFERENCES}

1. Балабанова Л.В., Алачева Т.И. Информационное обеспечение обоснования управленческих решений в условиях маркетинговой ориентации предприятия: монография. Донецк: ДонГУЭТ им. М. ТуганБарановского, 2003. 143 с. 
2. Бараш Є.Ю. Інформаційне забезпечення управління Державною кримінальною-виконавчою службою. Форум права. 2011. № 3. С. 34-40. URL: http://www.nbuv.gov.ua/e-journals/FP/2011-3/11beikvc.pdf.

3. Бондаренко Є.Д. Особливості інформаційного забезпечення торгівельного підприємства. Актуальні проблеми сучасної науки: п'ята всеукраїнська науково-практична інтеренет-конференція. URL: http://intkonf.org/bondarenko-ed-osoblivosti-informatsionogozabezpechennya-torgovelnogo-pidpriemstva.

4. Бринцев О.В. "Електронний суд" в Україні. Досвід та перспективи: монографія. Х.: Право, 2016. 72 с.

5. Ефективність роботи судів за 2017 рік / Державна судова адміністрація України. URL: https://ln.kr.court.gov.ua/dsa/pokaznikidiyalnosti/efekt_roboti_sudiv1/efekt_2017.

6. Єдина інформаційно-телекомунікаційна система може запрацювати в січні 2019 року. URL: https://kievskiysud.od.ua/pressdepartment/all-news/6577-edina-informatsijno-telekomunikatsijna-sistemamozhe-zapratsyuvati-v-sichni-2019-roku.

7. Информационные технологии управления: учеб. пособие для вузов / под ред. Г.А. Титоренко. 2-е изд., доп. М.: ЮНИТИ-ДАНА, 2003. $439 \mathrm{c}$.

8. Іерусалимов I.О. Поняття “забезпечення” у юридичній науці. Науковий вісник Київського національного університету внутрішніх справ. 2007. № 1. С. 11-17.

9. Калюжний Р.А., Гавловський В.В., Гуцалюк М.А. та ін. Інформаційному суспільству України інформаційне законодавство (щодо питань реформувань у сфері суспільних інформаційних відносин). Правове, нормативне та метрологічне забезпечення системи захисту інформації в Україні. 2001. № 2. С. 7-11.

10. Кодекс адміністративного судочинства України: Закон України від 6 липня 2005 р. № 2747-IV / Верховна Рада України. Відомості Верховної Ради України. 2005. № 35-37. Ст. 446.

11. Конституція України: Закон України від 28 червня 1996 p. № 254к/96-ВР / Верховна Рада України. Відомості Верховної Ради України. 1996. № 30. Ст. 141.

12. Корчинський О.I. Інформаційне забезпечення судової діяльності. IT право: проблеми і перспективи розвитку в Україні: матер. другої міжнар. щорічної конф. URL: http://aphd.ua/publication-257/.

13. Костенко О.В. Інформаційне забезпечення регіональних прокуратур та інформація з обмеженим доступом. Форум права. 2016. № 1. C. 116-123. URL: http://nbuv.gov.ua/UJRN/FP_index.htm_2016_1_21. 
14. Лушер В.В. Поняття інформаційного забезпечення органів прокуратури України. Форум права. 2014. № 1. С. 338-341. URL: http://nbuv.gov.ua/UJRN/FP_index.htm_2014_1_59.

15. Макушев П.В. Персональні дані як елемент системи інформаційного забезпечення державної виконавчої служби України. Форум права. 2013. № 2. С. 333-339. URL: http://nbuv.gov.ua/UJRN/ FP_index.htm_2013_2_51.

16. Макушев П.В. Система інформаційного забезпечення державної виконавчої служби України та персональні дані як їх складові. Право і суспільство. 2013. № 4. С. 70-77.

17. Нечитайло О.М. Адмінсуди організовують роботу так, щоб суспільство могло примусити органи державної влади та посадовців поважати права громадян. URL: http://www.vasu.gov.ua/archive/123741/.

18. Новий тлумачний словник української мови: в 4 т. / укл.: В.В. Яременко, О.М. Сліпушко. К.: Аконіт, 1999. 941 с.

19. Овчинников Є.І., Швець М.Я., Клімашевська Ю.А. Системна інформатизація кримінального судочинства. URL: http://www.scourt.gov.ua/ clients/vs.nsf/0/0206ECB2F1B9A93988256DA50066A8E3?OpenDocument.

20. Олійченко I.M. Інформаційне забезпечення управління обласною державною адміністрацією. URL: http://www.dridu.dp.ua/zbirnik/201101(5)/ 11 oimoda.pdf.

21. Петренко С.M. Інформаційне забезпечення внутрішнього контролю господарських систем: монографія. Донецьк: ДонНУЕТ, 2007. $290 \mathrm{c}$.

22. Положення про автоматизовану систему документообігу суду: Рішення Ради суддів України від 26 листопада 2010 р. № 30 (у редакції рішення Ради суддів України від 2 березня 2018 р. № 17) / Рада суддів України. URL: https:/court.gov.ua/sudova-vlada/969076/polozhenniapasds/.

23. Положення про автоматизовану систему документообігу суду: Рішення Ради суддів України від 26 листопада 2010 р. № 30 / Рада суддів України. URL: https://court.gov.ua/sudova-vlada/969076/polozhenniapasds/.

24. Про автоматизовану систему документообігу в адміністративних судах: Наказ Державної судової адміністрації України від 3 грудня 2009 р. № 129 / Державна судова адміністрація України. Офіційний вісник України. 2010. № 101. С. 393. Ст. 3566.

25. Про відчуження земельних ділянок, інших об'єктів нерухомого майна, що на них розміщені, які перебувають у приватній власності, для суспільних потреб чи 3 мотивів суспільної необхідності: Закон України від 17 листопада 2009 р. № 1559-VI / Верховна Рада України. Відомості Верховної Ради України. 2010. № 1. С. 3. Ст. 2. 
26. Про внесення змін до деяких законодавчих актів України щодо виборів Президента України: Закон України від 21 серпня 2009 р. № 1616-VI / Верховна Рада України. Відомості Верховної Ради України. 2009. № 50. С. 1816. Ст. 754.

27. Про внесення змін до деяких законодавчих актів України щодо запровадження автоматизованої системи документообігу в адміністративних судах: Закон України від 5 червня 2009 р. № 1475-VI / Верховна Рада України. Відомості Верховної Ради України. 2009. № 45. Ст. 683.

28. Про доступ до судових рішень: Закон України від 22 грудня 2005 p. № 3262-IV / Верховна Рада України. Відомості Верховної Ради України. 2006. № 15. Ст. 128.

29. Про електронний цифровий підпис: Закон України від 22 травня 2003 р. № 852-IV / Верховна Рада України. Відомості Верховної Ради України. 2003. № 36. Ст. 276.

30. Про електронні документи та електронний документообіг: Закон України від 22 травня 2003 р. № 851-IV / Верховна Рада України. Відомості Верховної Ради України. 2003. № 36. Ст. 275.

31. Про затвердження Інструкції 3 діловодства в адміністративних судах України: Наказ Державної судової адміністрації України від 17 грудня 2013 р. № 174 / Державна судова адміністрація України. URL: https://dsa.court.gov.ua/ userfiles/Nakaz\%20174.pdf.

32. Про затвердження Інструкції про порядок роботи 3 технічними засобами фіксування судового процесу (судового засідання): Наказ Державної судової адміністрації України від 20 вересня 2012 р. № 108 / Державна судова адміністрація України. Офіційний вісник України. 2012. № 77. Ст. 296.

33. Про затвердження Плану заходів щодо реалізації Державною судовою адміністрацією України Закону України "Про внесення змін до Господарського процесуального кодексу України, Цивільного процесуального кодексу України, Кодексу адміністративного судочинства України та інших законодавчих актів” від 3 жовтня 2017 р. № 2147-VIII: Наказ Державної судової адміністрації України від 22 грудня 2017 р. № 1126/ Державна судова адміністрація України. URL: https://dsa.court.gov.ua/ userfiles/file/DSA/DSA_2017_all_docs/17ordersmarch/N_1126.pdf.

34. Про затвердження Положення про Єдину базу даних електронних адрес, номерів факсів (телефаксів) суб'єктів владних повноважень: Постанова Кабінету Міністрів України від 5 січня 2011 р. № 5 / Кабінет Міністрів України. Офіційний вісник України. 2011. № 2. Ст. 102.

35. Про затвердження Порядку ведення Єдиного державного реєстру судових рішень: Постанова Кабінету Міністрів України від 25 травня 
2006 р. № 740 / Кабінет Міністрів України. Офіційний вісник України. 2006. № 22. Ст. 1623.

36. Про затвердження Типових посадових інструкцій працівників апарату місцевого загального суду: Наказ Державної судової адміністрації України від 20 липня 2005 р. № 86 / Державна судова адміністрація України. URL: http://zakon3.rada.gov.ua/rada/show/v0086750-05.

37. Про інформацію: Закон України від 2 жовтня 1992 р. № 2657-XII / Верховна Рада України. Відомості Верховної Ради України. 1992. № 48. Ст. 650.

38. Про Стратегію реформування судоустрою, судочинства та суміжних правових інститутів на 2015-2020 роки: Указ Президента України від 20 травня 2015 р. № 276/2015 / Президент України. Офіційний вісник Президента України. 2015. № 13. Ст. 864.

39. Про судоустрій і статус суддів: Закон України від 7 липня 2010 р. № 2453-VI / Верховна Рада України. Відомості Верховної Ради України. 2010. № 41-45. Ст. 529.

40.Про судоустрій та статус суддів: Закон України від 2 червня 2016 р. № 1402-VIII / Верховна Рада України. Відомості Верховної Ради України. 2016. № 31. С. 7. Ст. 545.

41.Пчелін В.Б. Правові засади інформаційного забезпечення адміністративного судочинства України. Підприємництво, господарство і право. 2016. № 8. С. 120-124.

42. Пчелін В.Б. Перегляд адміністративних актів органів внутрішніх справ: дис. ... канд. юрид. наук: 12.00.07 “Адміністративне право i процес; фінансове право; інформаційне право”. Х., 2011. 190 с.

43. Пчелін В.Б. Сутність інформаційного забезпечення адміністративного судочинства в Україні. Науковий вісник Ужгородського національного університету. Серія “Право”. 2016. № 39. С. 22-25.

44. Рішення Конституційного Суду України від 8 грудня 2011 p. № 16-рп/2011 (справа про фіксування судового процесу технічними засобами) / Конституційний Суд України. Вісник Конституційного Суду України. 2012. № 1. С. 31.

45. Роїк О.В. Електронне судочинство. Чи має Україна шанси? URL: http://yur-gazeta.com/dumka-eksperta/elektronne-sudochinstvo-chi-maeukrayina-shansi.html.

46. Словник української мови: в 11 т. / за ред. І.К. Білодіда. К.: Наукова думка, 1972. Т. 3. 630 с.; Словник української мови: в 11 т. / за ред. І.К. Білодіда. К.: Наукова думка, 1977. Т. 8. 927 с.

47. Туркіна I.C. Інформаційні технології в судовій системі. URL: http://www.kbuapa.kharkov.ua/e-book/putp/2011-3/doc/4/05.pdf. 
48. Черноіваненко А.В., Галунько В.В. Інформаційне забезпечення підготовки, прийняття та реалізації управлінських рішень: теоретичний підхід до визначення поняття. URL: http://www.kbuapa.kharkov.ua/ebook/conf/2009-1/doc/35.pdf.

49. Щодо Положення про автоматизовану систему документообігу суду: Рішення Ради суддів України від 26 листопада 2010 р. № 30 / Рада суддів України. Вісник Верховного Суду України. 2010. № 51. С. 5.

50. Юдін О.К., Богуш В.М. Інформаційна безпека держави: навч. посібник. Х.: Консум, 2005. 576 с.

\section{Information about the author:}

Shkuta O. O.,

Doctor of Juridical Sciences, Associate Professor, Professor at the Department of Professional and Special Disciplines, Kherson Faculty of Odessa State University of Internal Affairs

1, Fonvizina str., Kherson, Ukraine 